\title{
Therapeutic Effectiveness of a Siddha Formulation Arootha Chooranam: A Review
}

\author{
Jayashree $\mathbf{K}^{1}$, Kingsly $\mathbf{A}^{\mathbf{2}}$ \\ ${ }^{1}$ PG Scholar, Department of Gunapadam, ${ }^{2}$ Reader, Department of Gunapadam, \\ Government Siddha Medical College, Palayamkottai, Tirunelveli, Tamil Nadu, India. \\ Corresponding Author: Jayashree K
}

\begin{abstract}
Siddha system of medicine is the one of the ancient system of medical practiced among Tamil speaking community. The medicine in this system prepared from raw drug from only herbals. Arootha chooranam is a herbal preparation with ingredients of 9 herbals. It's used to treat the sexual desire disease particularly for indiriyanastam [pre mature ejaculation]. This review is aimed to bring out scientific evidence for the therapeutic usage of Arootha chooranam and focused on the pharmacological activity for the curative nature of the drug. Most of the drugs have anti-oxidant activity and anti-infertility, spermatogenesis, Aphrodisiac activity hence justifying its usage in above mentioned disease.
\end{abstract}

Keywords: Siddha medicine, Arootha chooranam, indiriyanastam, pharmacological activity.

\section{INTRODUCTION}

Siddha medicine is one of the most ancient medical systems of India. The word siddha comes from the Tamil word for perfection. In siddha medicine the individual is a microcosm of universe. Siddha medicines are known for its efficacy and safety. The reason for popularity of the siddha system is attributed to its effective with minimal side effect. Siddhars the founder of siddha system possessed yoga siddhi powers [supernatural powers]. They have left their imprints in many disciplines like medicine alchemy, philosophy, yogam, and varmam.

Aroothachooranam is classical siddha compound drug which is mentioned in siddha text book of Chikiccha Rathna Deepam Ennum Vaithiya Sinthamani Pagam 11. This drug used for sexual desire disease particularly for indiriyanastam [pre mature ejaculation]. The drug review of AroothaChooranam is a compound herbal drug gives sound evidence for its therapeutic action mentioned in literature. The major ingredients of this drug sadap leaf, fenugreek, seenakarkandu and dhaniya. This review focused on the pharmacological activites of each ingredient which supports the traditional claim and the literature search is confined to that area. The search was made from the textbooks in the library of govt siddha medical college of palayamkottai, journals, internet database etc.

\section{Standard operating procedure for preparation of Aroothachooranam: Purification of raw drugs:}

All the raw drugs are purified as per the methods mentioned in siddha literature.

\section{Preparation of drug Aroothachooranam:}

The mentioned ingredients in the table 1 are powdered separately and mixed well together then taken in a tightly closed container. 
Table 1 : Method of preparation of Aroothachooranam

\begin{tabular}{|l|l|l|l|l|l|}
\hline S.No & Tamil Name & Botanical Name & Family & Party Used & Quantity \\
\hline 1. & Vendhayam & Trigonellafoneumgraceum & Fabaceae & Seed & 8varagan \\
\hline 2. & Sathappuilai & Rutachalepensis & Rutaceae & leaves & 8varagan \\
\hline 3. & Seeragam & Cuminumcyminum & Apiaceae & Seed & 8varagan \\
\hline 4. & Karunjchiragam & Nigella sativa & Rananculaceae & Seed & 8varagan \\
\hline 5. & Seenalavangapattai & Cinnamomumverum & Lauraceae & Bark & 8varagan \\
\hline 6. & Athimathuram & Glycyrrhizaglabra & Fabaceae & Bark & 8varagan \\
\hline 7. & Sombu & Pimpinellaanisum & Apiaceae & Seed & 8varagan \\
\hline 8. & Dhaniya & Coriandrumsativum & Apiaceae & Seed & 50varagan \\
\hline 9. & SeenaKarkandu & Saccharumofficinarum & Poaceae & Sugar Candy & 25varagan \\
\hline
\end{tabular}

Table 2: Information of herbal ingredients as per siddha the text GunapadamMooligaiVaguppu

\begin{tabular}{|c|c|c|c|c|c|c|}
\hline S.No & Botanical name & Veranacular name & & & & Part used \\
\hline & & Tamil & English & Hindi & Sanskrit & \\
\hline 1. & Trigonellafoceumgraceum & Vendhayam & Fenugreek & Methi & Methi & Seed \\
\hline 2. & Rutachalepensis & Sathappuilai & Garden rue & Sada & Sadap & leaves \\
\hline 3. & CuminumCyminum & Seeragam & $\begin{array}{l}\text { Cumin seeds or } \\
\text { fruits }\end{array}$ & zira & Jirakams & Seed \\
\hline 4. & Nigella sativa & Karunjchiragam & Black cumin & Kulanji,kala - zira & Upakunchika & Seed \\
\hline 5. & Cinnamomumverum & Seenalavangapattai & $\begin{array}{ll}\text { Bark } & \text { of } \\
\text { Cinnamon } & \\
\end{array}$ & Dar_Chini & Twak & Bark \\
\hline 6. & Glycyrrhizaglabra & Athimathuram & $\begin{array}{l}\text { Jequlity } \\
\text {;Jamicaliquorice }\end{array}$ & $\begin{array}{l}\text { Jathi_Madh, } \\
\text { Mulath }\end{array}$ & Yashti_Madhukam & Bark \\
\hline 7. & Pimpinellaanisum & Sombu & $\begin{array}{l}\text { Anise seeds; } \\
\text { anise fruit }\end{array}$ & & Sthula_jeekakam & Seed \\
\hline 8. & Coriandrumsativum & Koththumali & Coriander seeds & Dhaniya & $\begin{array}{l}\text { Kustumbari } \\
\text { Dhaniyaka }\end{array}$ & Seed \\
\hline 9. & Saccharumofficinarum & Seenakarkandu & $\begin{array}{l}\text { Sugarcane, } \\
\text { Noble cane }\end{array}$ & Ukh_Ganna & Ikshu,Rasalah & $\begin{array}{l}\text { Sugar } \\
\text { Candy }\end{array}$ \\
\hline
\end{tabular}

Pharmacological activities of ingredients of Arootha chooranam :

Vendhayam [Trigonella foenum-graecum]: Phytochemical screening of ethanolic extract of trigonella foenumgraecum through maceration and soxhlet method determine presence of alkaloids, saponins, terpenoids, anthraquinone glycosides, tannins, carbohydrates and phenol in the seeds. The anti oxidant activity of the plant extract was assessed through the method of DPPH test while total amount of phenolic compound in the extract can be determined through TPC test .Antioxidant activity which may be helpful in preventing or slowing progress of disease involved as a result of oxidative disease. Aqueous solution of the extract [250mg/kgb.wt/day] when administered orally for 45 days to adult male albino rat [ductray strain]. Seeds extract caused inhibit spermatogenesis as well as inability to mate with normal untreated female rats of proven fertility.

\section{Sathappuilai[Rutachalepensis]}

rutagraveolens are reported in British and Denmark's traditional methods leaf extract of rutagraveolens have free radical scavenging Activity that can be profitable for action against liver damage and also shows significant antidiabetic and antioxidant activity (Pinky Pandey et al. 2011). sadap is widely distributed in sudan and other Afro-Asian countries is used in traditional medicine as an aphrodisiac, emmenagogue and analgesic and treatment of a variety of ailments from cramp to hysteria helminthosis, skin condition and disease of the womb (el agraa et al.,2002).

\section{Seeragam [Cuminumcyminum]}

Some of the bioactive components of cumin present. They are thymol, vanillin and limonene. Pharmacological activity of cumin and its active components shows an antioxidant anticarcenogenic, immunomodulatory activities. cumin consists of very high amount of antioxidant compounds this antioxidant activity is due to linalool, monoterpenes. It protects the cells against oxidative stress caused by free radicals that cause the aging process. Its protection against all types of degenerative diseases such as cancer, heart disease etc. 
various method being used to test the antioxidant activity of cumin its documented that cumin have the ability to quench hydroxyl radical, lipid; peroxides1, 1 dephenyl 2-picryhydrazyl (DPPH) radical.

\section{Karunjichiragam [Nigella sativa]}

Nigella sativa seed contains a complex mixture of more than 100 compounds. Most of the therapeutic properties of nigella sativa due to the presence of the polyphenol thymoquinone which is the major component (28-57\%). This seed oil and thymoquinoneexhibited spermioprotective effect against testes damage. This seed oil increase number of leydig cells in rat test beside the presence of unsaturated fatty acid in nigella sativa oil stimulate 17 L- hydroxysteriod dehydrogenase activity thus increasing testosterone level. This study with both infertile men and rats have found that black seed oil can boost sperm count and help sperm swim faster. Antioxidant in the oil likely help protect sperm from damage.

\section{Seenalavangapattai [Cinnamomum verum]}

Cinnamon is one of these plants which is commonly used as food spice medicinally as antioxidant, anti inflammatory, antidiabetic, due to the presence of some phytochemical ingredients such as polyphenols. Several scientific researchers reported that cinnamon extract showed significant improvement in hyperglycemia, hyperlipidemia, and infertility. The present study showed that alloxan-induced diabetic male rats suffer from abnormal fertility measurements including serum testosterone levels, epididymis weight sperm count, motility and morphology. These parameters were markedly improved after 4 weeks of cinnamon powder treatment. It is well known that diabetes is positively correlated with male infertility and sexual dysfunction. This impairment occurred due to hormonal changes, neuropathy and increased oxidative stress aspects. Our results, demonstrated higher effect of cinnamon on fertility parameters compared to previous reports. this effect can be attributed to the presence of many ingredients in cinnamon powder bark work together as synergistic combination compared to those found in separate extracts. It could be deduced that taking cinnamon as food spice regularly might improve fertility even in normal healthy persons as well as diabetic patients.

\section{Athimaduram[glycyrrhizaglabbra]:}

Glycyrrhizaglabra L. is one of the very important nutraceuticals contains 400 bioactive phytochemicalsj and has many documented bioactivities such as steroid like activity powerful antioxidant activity and antibacterial activity and antiviral activity. Licorice was considered as a natural source of sex hormones and used to female reproductive system treat some women's sterility cases in Jap and China strengthen male reproductive system improve sperm count as well as semen viscosity in ayurvedic medicine and improve erection The effects licorice extract (glycyrrizhaglabra) addition to semen diluters on ram sperm progressive motility during storage at $5 \mathrm{c}$ for 72 hours semen was collected from 3 proven awassi rams. Licorice extract powder was added at 24,48 , and $72 \mathrm{~h}$ of storage. The experiment was replicated 2 times with yolk glucose citrate diluter. 'Progressive motility increased significantly $(p<0.01)$ in levels of licorice extract $1,5,10,50$ and $100 \mathrm{ug} / \mathrm{ml}$ in both diluters during all storage periods. The means of progressive motility were $72.5+$ $1.02 \% 72.08+1.05,70.90+2.05 \%$ and $66.25+3.15 \%$ respectively compared to the control (0) $61.45+16.2 \%$ levels 1,5 and $10 \mathrm{ug} / \mathrm{ml}$ were superior $(\mathrm{p}<0.01)$ to level 50 and $100 \mathrm{ug} / \mathrm{ml}$. In conclusion the addition of licorice extract to the diluter improved ram sperm progressive motility during cooled storage at $5^{\circ} \mathrm{C}$. 


\section{Sombu [pimpellaanisum]}

Aniseed is one of the important medicinal plants in siddha system of medicine. The recent studies especially on seeds and essential oil in vivo antioxidant potential; the ethanolic extract of aniseed displayed scavenging activity against nitric oxide (NO) superoxide and 1,1 diphenyl, 2picrylhydrazyl radicals and reducing power in a concentration - dependent manner Anisiaetheroleum exerted hepatoprotective effect through antioxidant activity by serum antioxidant enzymes as well as oxidative stress and peroxides inhibition. Aniseed a very popular aphrodisiac is believed to have special power sucking on the seed increase sexual desire.

\section{Koththumali [coriandrumsativum]:}

Coriander is a glabours aromatic herbaceous annual plant which is well known for its use in jaundice. it has a very effective antioxidant profile showing 2,2 diphenyl-1-picrylhydrazyl (DPPH) radical scavenging activity, lipoxygenase inhibition phospholipid peroxidation inhibition, iron chelating activity, hydroxyl radical scavenging activity, superoxide dismutation, glutathione reduction and antilipid peroxidation due to high total phenolic content with presence of constitutents like pyrogallol, caffeic acid, glycitin. Aqeous extract of coriandrumsativum $\mathrm{s}$ seed has been recommended for relief of anxiety and insomnia, and may have potential sedative, hypotensive and muscle relaxant effects. Aqeous seed extract of coriander on spermatogenesis and sperm parameters mice. Histological results showed that sperm numbers significantly $(\mathrm{P}<0.05)$ increased in the luminal spermatozoa in both concentrations of coriander compared with control. Also more investigation are needed to prove the coriander is useful for fertility of other species.

\section{Seenakarkandu \\ [Saccharumofficinarum]:}

Phenolic compound in sugarcane juice were identified. Sugar cane juice increase vigour and sexual ability. It act as an aphrodisiac and increase libido, quantity and quality of semen. The phenolic extract obtained from sugar cane juice showed a protective effect aganistin vivo Mehgcl intoxication and potent inhibition of ex vivo lipoperoxidation of rat brain homogenates, indicating a potential use for beneficial health effects and/ ortherapeutic application. A sugar cane extract (SCE) has been found to have an immune stimulating effect in several animals. Results suggest that SCE has a protective effect on LPS induced endotoxin shock via one possible mechanisms involving the suppression of NO production in the mouse peritoneal cavity.

\section{CONCLUSION}

From this literature review it is evident that the most of ingredients of Aroothachoonaranam has pharmacological activity of anti fertility, anti oxidant activity, Aphrodisiac, spermatogenesis activity, which are responsible for its therapeutic activity claimed in literature.

\section{Acknowledgement: None}

\section{Conflict of Interest: None}

\section{Source of Funding: None}

\section{REFERENCES}

1. ChikicchaRathnaDeepamEnnumVaithiyaSin thanmaniPagam 2 page no 168

2. GunapadamMooligaiVaguppu

3. Essential of medical pharmacology 6 th edition.

4. Haseena $\mathrm{S}$ et al. Effect of Nigella sativa seed powder on testosterone and LH levels in sterptozotocine induced diabetic male albino rats. J.pharmsci 2015, vol.7(4) 234237

5. Madulikasinghand G. N .Verma 2019 Effect of Ethanolic Extract of Trigonella foenumgraecum L. seeds on Reproductive 
system Male Article no. JOCAMR 53003 ISSN 2456-6276

6. Pharm pharmacolint J: 2019 Phytochemical screening antimicrobial and antioxidant activity determination of TrigonellaFoenumGraecumVol 7 (4) 175186

7. IBNAL- Haitham for pure \$ APPL .Scl. Effects of Licorice Extract on Sperm motility of chilled stored Ram semen Vol 23 (1) 2010

8. Mahmoud AI- Shawabkeh and AbdulrahimAI Jamal Effect of Cinnamon Administration on Fertility of Normal and Diabetic Male Rats 2019 Vol 18 | Issue 5 | page no 491-495

9. Nesreen I .EI. Sanusi and S. EI. Adam The Effect of low levelof dietary Rutagraveolens and sclenostemmaargel or their mixture on bovans chicks year :2007| volume :2| issue:1| page no:27-31

10. AbhilashaBharagavaRanjanaVarma And Alkaverma medicinal properties of
Rutagraveolens L. A plenteous life saver Vol(5) ; Issue 4; 2020; Page no 36-39

11. Shah rupalk.,Patel PriyankaJ, Trivedi Goral and Saraf Meenu Mini review cumin: A Natural drug research gate

12. DR. Vandna Pathak and vipin Kumar Tiwari Phytochemical Screening of Saccharum Officinarum (linn).stem Vol2 (8)(2017)

13. Jinous Asgarpanah and Nastaran Kazemivash Phytochemistry, pharmacology and medicinal properties of Coriandrum Sativum L. Vol (6) (2012) 2340-2345

14. J Joseph Thas. Clin Dermatol .Siddha medicine- background and principles and the application for skin disease, 26(1) (2008)62-78.

How to cite this article: Jayashree K, Kingsly A. Therapeutic effectiveness of a siddha formulation arootha chooranam: a review. Int $J$ Health Sci Res. 2021; 11(5): 146-150. DOI: https:// doi.org/10.52403/ijhsr.20210522 